\title{
Positive Correlation Between Regional Cerebral Oxygen Saturation and Mixed Venous Oxygen Saturation During Off-Pump Coronary Artery Bypass Surgery
}

\author{
Zheng Guan MD, Jing-Jie Liu MD, Hui Yuan MD, and Yan-Feng Gao MD
}

\begin{abstract}
BACKGROUND: The balance of oxygen delivery and consumption is essential in patients who are critically ill. Mixed venous oxygen saturation $\left(S_{\bar{v} O_{2}}\right)$ is a standard method to evaluate oxygen delivery and consumption during anesthesia. However, $\mathrm{S}_{\overline{\mathrm{v}} \mathrm{O}_{2}}$ is monitored through a pulmonary artery catheter, which is invasive. Regional cerebral oxygenation $\left(\mathrm{rScO}_{2}\right)$ reflects oxygen saturation in a small region of the frontal lobes and is monitored noninvasively through near-infrared spectroscopy. In the present study, the correlation between $\mathrm{rScO}_{2}$ and $\mathrm{S}_{\overline{\mathrm{v}} \mathrm{O}_{2}}$ was calculated during off-pump coronary artery bypass grafting surgery to determine whether a positive correlation exists between $\mathrm{rScO}_{2}$ and $\mathrm{S}_{\overline{\mathrm{v}}}{ }_{2}$. METHODS: A total of 56 subjects were consecutively enrolled in the study. Then $\mathrm{rScO}_{2}$ and $\mathrm{S}_{\overline{\mathrm{v}}} \mathrm{O}_{2}$ were simultaneously monitored. The parameters were recorded at 5 time points: $T_{1}, 10 \mathrm{~min}$ after intubation $\left(1.0 \mathrm{~F}_{\mathrm{IO}_{2}}\right.$ for $\left.10 \mathrm{~min}\right) ; \mathrm{T}_{2}, 20 \mathrm{~min}$ after intubation $\left(0.60 \mathrm{~F}_{\mathrm{IO}_{2}}\right.$ for $10 \mathrm{~min})$; $\mathrm{T}_{3}$, at the end of the revascularization of the left anterior descending artery $\left(0.60 \mathrm{~F}_{\mathrm{IO}_{2}}\right)$; $T_{4}$, after protamine infusion $\left(0.60 \mathrm{~F}_{\mathrm{IO}_{2}}\right)$; and $\mathrm{T}_{5}$, 10 min after protamine infusion $\left(1.0 \mathrm{~F}_{\mathrm{IO}_{2}}\right.$ for $10 \mathrm{~min}$ ). The correlation between $\mathrm{rScO}_{2}$ and $\mathrm{S}_{\overline{\mathrm{v}} \mathrm{O}_{2}}$ and the variation trend between $\mathrm{rScO}_{2}$ and $\mathrm{S}_{\overline{\mathrm{v}}}$ when $\mathrm{F}_{\mathrm{IO}_{2}}$ increased from 0.60 to 1.0 were analyzed. RESULTS: There was a significant positive correlation between $\mathrm{rScO}_{2}$ and $\mathrm{S}_{\overline{\mathrm{v}}} \mathrm{O}_{2}$ at these 5 time points $\left(\mathrm{r}^{2}=0.77,0.81,0.70,0.83\right.$, and 0.92 , respectively). There also was a significant positive correlation between $\Delta \mathrm{rScO}_{2}$ and $\Delta \mathrm{S}_{\overline{\mathrm{v}}} \mathrm{O}_{2}(n=112$, $\left.\mathbf{r}^{2}=0.72, P<.001\right)$. Linear regression analysis revealed that $\mathrm{S}_{\bar{v}_{2}}$ had a positive correlation with $\mathrm{rScO}_{2}$ and cardiac output $\left(r^{2}=0.68, P=.013\right)$. CONCLUSIONS: There was a positive correlation between $\mathrm{rScO}_{2}$ and $\mathrm{S}_{\overline{\mathrm{v}}}$, during off-pump coronary artery bypass grafting surgery, and there also was a positive correlation in the variation trend between $\mathbf{r S c O}_{2}$ and $\mathbf{S}_{\overline{\mathbf{v}}} \mathbf{O}_{2}$. Key words: near-infrared spectroscopy; pulmonary artery catheterization; off-pump coronary artery bypass. [Respir Care 2018;63(8):988-993. () 2018 Daedalus Enterprises]
\end{abstract}

\section{Introduction}

Maintaining adequate oxygen saturation is essential for patients who are critically ill. Mixed venous oxygen sat-

Drs Guan, Yuan, and Gao are affiliated with Department of Anesthesiology, the First Affiliated Hospital of Xi'an Jiaotong University, Shaanxi, China. Dr Liu is affiliated with Department of Neurology, the Second Affiliated Hospital of Xi' an Jiaotong University, Shaanxi, China.

This work was supported by the Department of Cardiac Surgery, the First Affiliated Hospital of Xi' an Jiaotong University, Shaanxi, China.

The authors have disclosed no conflicts of interest.

Correspondence: Jing-Jie Liu MD, Department of Neurology, The Second Affiliated Hospital of Xi' an Jiaotong University, No. 157 of uration $\left(\mathrm{S}_{\overline{\mathrm{v}}_{\mathrm{O}}}\right)$ remains the accepted standard during anesthesia to evaluate the balance of oxygen delivery and consumption, especially during cardiac surgery. ${ }^{1} \mathrm{~S}_{\overline{\mathrm{v}} \mathrm{O}_{2}}$ is monitored through the pulmonary artery catheter, but many complications are associated with pulmonary artery catheter placement, such as bleeding, arrhythmia, and pulmonary artery rupture. ${ }^{2}$ Hence, this cannot be routinely used during anesthesia. A noninvasive tool to monitor systemic oxygen balance would have a much wider application.

Xiwu Road, Xincheng District, Shaanxi 710004, China. E-mail: liujingjie0923@163.com.

DOI: $10.4187 /$ respcare. 05772 
Near-infrared spectroscopy can noninvasively and continuously estimate the regional oxygen delivery-consumption balance in an underlying tissue. It is based on oxyhemoglobin and deoxyhemoglobin each having their own particular optical absorption characteristics. ${ }^{3}$ Near-infrared spectroscopy can monitor regional cerebral oxygen saturation $\left(\mathrm{rScO}_{2}\right),{ }^{4}$ which reflects oxygen saturation in a small region of the frontal lobes. Furthermore, $\mathrm{rScO}_{2}$ has been used in preterm and term neonates, ${ }^{5}$ in patients during cardiac surgery ${ }^{6}$ neurosurgery, and in patients with head trauma. ${ }^{7}$ Moreover, $\mathrm{rScO}_{2}$ can detect disturbances of regional tissue perfusion and oxygenation, ${ }^{8}$ and predict low output syndrome, ${ }^{9}$ cognitive decline, and a prolonged hospital stay after cardiac surgery. ${ }^{10}$

Results of one study indicated that $\mathrm{rScO}_{2}$ is useful for indicating global oxygen delivery and consumption, ${ }^{11}$ and the correlation between $\mathrm{rScO}_{2}$ and $\mathrm{S}_{\overline{\mathrm{v}}}$, has been studied in adult and pediatric cardiac surgery patients. ${ }^{12,13}$ To determine whether $\mathrm{rScO}_{2}$ can be a noninvasive technique to reflect systemic oxygen balance, we investigated the correlation between $\mathrm{rScO}_{2}$ and $\mathrm{S}_{\overline{\mathrm{v}}_{2}}$ in off-pump coronary artery bypass grafting surgery under both 0.60 and $1.0 \mathrm{~F}_{\mathrm{IO}_{2}}$ during mechanical ventilation. The purpose of this study was to determine whether both $\mathrm{rScO}_{2}$ and $\mathrm{S}_{\overline{\mathrm{v}}_{2}}$ could be applied, instead of one or the other.

\section{Methods}

The study protocol of this prospective observational study was approved by the ethics committee of the First Affiliated Hospital of Xi' an Jiaotong University. Written informed consent was obtained from all the subjects. From January to December 2015, a total of 56 subjects were enrolled into this study. Inclusion criteria were the following: age $>18$ y and elective off-pump coronary artery bypass grafting surgery for coronary heart disease. Exclusion criteria were the following: combined other cardiac surgeries, contraindication of pulmonary artery catheter placement, stroke, cerebrovascular disease, intra-aortic balloon pump or other ventricle support devices used during the operation, failure to insert the pulmonary artery catheter, and death during the operation. The enrollment procedure is shown in Figure 1.

\section{Anesthesia Management}

The subjects were routinely monitored by electrocardiogram, pulse oxygen saturation, arterial blood pressure, and central venous pressure. Anesthesia was induced by $0.05-$ $0.10 \mathrm{mg} / \mathrm{kg}$ midazolam, $0.5-1.0 \mu \mathrm{g} / \mathrm{kg}$ sufentanil, $0.2-$ $0.3 \mathrm{mg} / \mathrm{kg}$ etomidate, and $0.9 \mathrm{mg} / \mathrm{kg}$ rocuronium, which was maintained by $1.0-1.5 \%$ sevoflurane and $4-8 \mathrm{mg} / \mathrm{kg} / \mathrm{h}$ propofol, muscle relaxation was achieved by rocuronium. Mechanical ventilation was performed in the volume control mode with a breathing frequency of 10 breaths/min and a tidal volume of $6-12 \mathrm{~mL} / \mathrm{kg}$. The tidal volume was adjusted to

\section{QUICK LOOK}

\section{Current knowledge}

Mixed venous oxygen saturation $\left(\mathrm{S}_{\overline{\mathrm{v}}}{ }_{2}\right)$ is a standard method to evaluate global oxygen delivery and consumption balance during anesthesia. The regional cerebral oxygen saturation $\left(\mathrm{rScO}_{2}\right)$, which can be noninvasively monitored by near-infrared spectroscopy, indicates the regional cerebral oxygen saturation and provides information on regional cerebral oxygen delivery and consumption balance. Previous studies showed that the $\mathrm{rScO}_{2}$ could indicate global oxygen delivery and consumption, and there was correlation between $\mathrm{rScO}_{2}$ and $\mathrm{S}_{\overline{\mathrm{v}}_{2}}$ under some condition, but whether the correlation was existed during off-pump coronary artery bypass grafting surgery was not explored.

\section{What this paper contributes to our knowledge}

$\mathrm{rScO}_{2}$ would be adequate in reflecting $\mathrm{S}_{\overline{\mathrm{v}}_{2}}$ and the variation trend of $\mathrm{S}_{\overline{\mathrm{v}}_{2}}$ during off-pump coronary artery bypass grafting surgery, the change in $\mathrm{F}_{\mathrm{IO}_{2}}$ can simultaneously influence the $\mathrm{rScO}_{2}$ and $\mathrm{S}_{\overline{\mathrm{v}}} \mathrm{F}_{2}$ value, and the variation trend of $\mathrm{rScO}_{2}$ and $\mathrm{S}_{\mathrm{vO}_{2}}$ was consistent.

maintain the end-tidal carbon dioxide pressure at 35 $45 \mathrm{~mm} \mathrm{Hg}$. $\mathrm{F}_{\mathrm{IO}_{2}}$ was 1.0 during anesthesia induction. This was reduced to 0.60 at $10 \mathrm{~min}$ after intubation and increased to 1.0 again after protamine infusion.

\section{$\mathrm{S}_{\overline{\mathrm{v}} \mathrm{O}_{2}}$ and $\mathrm{rScO}_{2}$ Measurements}

$\mathrm{S}_{\overline{\mathrm{v}}_{2}}$ and $\mathrm{rScO}_{2}$ were simultaneously monitored in all the subjects. After anesthesia induction, the pulmonary artery catheter (Swan-Ganz Continuous Cardiac Output Thermodilution catheter, Edwards Lifesciences, Irvine, California) was inserted via an 8.5 French sheath placed in the right internal jugular vein for all the subjects. $\mathrm{S}_{\mathrm{vO}_{2}}$ was continuously measured through the pulmonary artery catheter connected to a Vigilance II monitor (Edwards Lifesciences). The location of the pulmonary artery catheter was verified by pressure curve analysis. The $\mathrm{rScO}_{2}$ was continuously measured by nearinfrared spectroscopy. The near-infrared spectroscopy sensors (at a wavelength of 700-900 nm) were placed on the right side of the forehead with a flexible, self-adhesive bandage wrapped around the head. These sensors were connected to a EGOS-600A cerebral oximeter (EnginMed, Suzhou, China).

\section{Data Collection}

Next, $\mathrm{rScO}_{2}$ and $\mathrm{S}_{\overline{\mathrm{v}}} \mathrm{O}_{2}$ were recorded at 5 time points: $\mathrm{T}_{1}, 10 \mathrm{~min}$ after intubation (mechanical ventilation with 


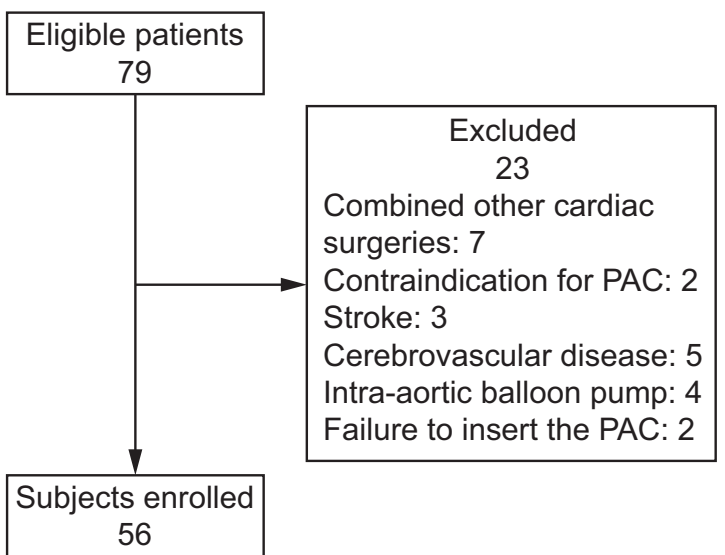

Fig. 1. Flow chart. PAC = pulmonary artery catheter.

$1.0 \mathrm{~F}_{\mathrm{IO}_{2}}$ for $10 \mathrm{~min}$ ); $\mathrm{T}_{2}, 20 \mathrm{~min}$ after intubation (mechanical ventilation with $0.60 \mathrm{~F}_{\mathrm{IO}_{2}}$ for $10 \mathrm{~min}$ ); $\mathrm{T}_{3}$, the end of the revascularization of the left anterior descending artery (mechanical ventilation with $0.60 \mathrm{~F}_{\mathrm{IO}_{2}}$ ); $\mathrm{T}_{4}$, after protamine infusion (mechanical ventilation with 0.60 $\mathrm{F}_{\mathrm{IO}_{2}}$ ); and $\mathrm{T}_{5}, 10 \mathrm{~min}$ after protamine infusion (mechanical ventilation with $1.0 \mathrm{~F}_{\mathrm{IO}_{2}}$ for $10 \mathrm{~min}$ ). The demographics were recorded for all the subjects. Mean arterial blood pressure, central venous pressure, mean pulmonary artery pressure, cardiac output $\left(\dot{\mathrm{Q}}_{\mathrm{T}}\right), \mathrm{P}_{\mathrm{aO}_{2}} / \mathrm{F}_{\mathrm{IO}_{2}}, \mathrm{P}_{\mathrm{aCO}}$, and hemoglobin concentration were also recorded at these 5 time points.

\section{Statistical Analysis}

Continuous variables are presented as mean $\pm \mathrm{SD}$, and categorical variables are presented as numbers. Repeatedmeasures analysis of variance was used to assess the difference of mean arterial blood pressure, central venous pressure, mean pulmonary artery pressure, $\dot{\mathrm{Q}}_{\mathrm{T}}, \mathrm{P}_{\mathrm{aO}_{2}} / \mathrm{F}_{\mathrm{IO}_{2}}$, $\mathrm{P}_{\mathrm{aCO}_{2}}$, hemoglobin, $\mathrm{rScO}_{2}$, and $\mathrm{S}_{\overline{\mathrm{v}}_{2}}$ among the time points. The correlation between $\Delta \mathrm{rScO}_{2}$ and $\Delta \mathrm{S}_{\overline{\mathrm{v}}}{ }_{2}$ was evaluated by using the Pearson correlation coefficient. Linear regression analysis was calculated among $\mathrm{S}_{\mathrm{vO}_{2}}$ and $\mathrm{rScO}_{2}$, $\dot{\mathrm{Q}}_{\mathrm{T}}$, mean arterial blood pressure, central venous pressure, mean pulmonary artery pressure, hemoglobin, $\mathrm{P}_{\mathrm{aCO}}$, and $\mathrm{P}_{\mathrm{aO}} / \mathrm{F}_{\mathrm{IO}_{2}}$. Data were analyzed by using SPSS 17.0 for Windows (SPSS, Chicago, Illinois). Statistical significance was defined as $P<.05$.

\section{Results}

\section{Subject Demographics and Details of the Operation}

From January to December 2015, a total of 56 subjects were enrolled into the present study. Subject demographics and operation details are shown in Table 1.
Table 1. Demographic Data and Details of Operations of the Subjects

\begin{tabular}{lcc}
\hline \multicolumn{1}{c}{ Parameter $(N=56)$} & Value & Range \\
\hline Age, mean \pm SD y & $58.5 \pm 7.0$ & $45-67$ \\
Males/females, $n$ & $41 / 15$ & \\
BMI, mean \pm SD kg/m ${ }^{2}$ & $24.3 \pm 3.4$ & $19.4-29.4$ \\
Preoperative LVEF, mean \pm SD \% & $58.8 \pm 12.2$ & $35-73$ \\
Comorbidities, $n$ & & \\
$\quad$ Hypertension & 33 & \\
$\quad$ Diabetes & 24 & \\
$\quad$ Kidney injury & 5 & \\
Operation duration, mean \pm SD min & $215.7 \pm 57.2$ & $150-340$ \\
Grafts, mean \pm SD $n$ & $4.4 \pm 1.2$ & $2-6$ \\
& & \\
BMI $=$ body mass index & & \\
LVEF $=$ left-ventricle ejection fraction & & \\
\hline
\end{tabular}

\section{Hemodynamic Data and Arterial Blood Gas Analysis at 5 Time Points During Off-Pump Coronary Artery Bypass Grafting Surgery}

There was no significant difference in $\mathrm{P}_{\mathrm{aO}_{2}} / \mathrm{F}_{\mathrm{IO}_{2}}, \mathrm{P}_{\mathrm{aCO}_{2}}$, and hemoglobin among the 5 time points. The central venous pressure, mean arterial blood pressure, and mean pulmonary artery pressure were significantly higher at $\mathrm{T}_{3}$ than at the other time points, and $\dot{\mathrm{Q}}_{\mathrm{T}}$ was significantly lower at $\mathrm{T}_{3}$ and significantly higher at $\mathrm{T}_{5}$ than the other time points. These data are shown in Table 2.

\section{Correlation Between $\mathrm{rScO}_{2}$ and $\mathrm{S}_{\overline{\mathrm{v}}} \mathrm{O}_{2}$ Among the 5 Time Points}

$\mathrm{S}_{\overline{\mathrm{v}}}{ }_{2}$ and $\mathrm{rScO}_{2}$ were significantly higher at $\mathrm{T}_{5}$ than at the other time points. There was a positive correlation between $\mathrm{rScO} 2$ and $\mathrm{S}_{\overline{\mathrm{v}}_{2}}$ at the 5 time points. The data are presented in Table 3.

\section{Correlation of the Variation Trend Between $\mathrm{rScO}_{2}$ and $\mathrm{S}_{\overline{\mathrm{v}} \mathrm{O}_{2}}$ Under Different $\mathbf{F}_{\mathrm{IO}_{2}}$}

$\mathrm{rScO}_{2}$ and $\mathrm{S}_{\overline{\mathrm{v}}_{2}}$ decreased when $\mathrm{F}_{\mathrm{IO}_{2}}$ decreased from 1.0 to $0.60\left(\mathrm{~T}_{1}\right.$ to $\left.\mathrm{T}_{2}\right)$, and increased when $\mathrm{F}_{\mathrm{IO}_{2}}$ increased from 0.60 to $1.0\left(\mathrm{~T}_{4}\right.$ to $\left.\mathrm{T}_{5}\right)$. The $\Delta \mathrm{S}_{\overline{\mathrm{v}}_{2}}$ was defined as $\mathrm{S}_{\overline{\mathrm{v}}_{\mathrm{O}}}\left(\mathrm{T}_{1}\right)-\mathrm{S}_{\overline{\mathrm{v}}_{\mathrm{O}}}\left(\mathrm{T}_{2}\right)$ and $\mathrm{S}_{\overline{\mathrm{v}} \mathrm{O}_{2}}\left(\mathrm{~T}_{5}\right)-\mathrm{S}_{\overline{\mathrm{v}}_{2}}\left(\mathrm{~T}_{4}\right)$, whereas $\Delta \mathrm{rScO}_{2}$ was defined as $\mathrm{rScO}_{2}\left(\mathrm{~T}_{1}\right)-\mathrm{rScO}_{2}\left(\mathrm{~T}_{2}\right)$ and $\mathrm{rScO}_{2}\left(\mathrm{~T}_{5}\right)-\mathrm{rScO}_{2}\left(\mathrm{~T}_{4}\right)$. The mean $\pm \mathrm{SD} \Delta \mathrm{S}_{\overline{\mathrm{v}}}$. was $4.7 \pm 4.1$, and the mean $\pm \mathrm{SD} \Delta \mathrm{rScO}_{2}$ was $2.5 \pm 2.5$. The variation trend between $\mathrm{rScO}_{2}$ and $\mathrm{S}_{\overline{\mathrm{v}} \mathrm{O}_{2}}$ was consistent $\left(\mathrm{r}^{2}=0.72, P<.001\right)$ (Fig. 2). Linear regression analysis was performed to examine the variables that best predict $\mathrm{S}_{\overline{\mathrm{v}}_{\mathrm{O}}}$. Then $\mathrm{rScO}_{2}, \dot{\mathrm{Q}}_{\mathrm{T}}$, mean arterial blood pressure, central venous pressure, mean pulmonary artery pressure, hemoglobin, $\mathrm{P}_{\mathrm{aCO}_{2}}$, and $\mathrm{P}_{\mathrm{aO}} / \mathrm{F}_{\mathrm{IO}_{2}}$ were used in the model. 
Table 2. Hemodynamic Data and Arterial Blood Gas Analysis

\begin{tabular}{|c|c|c|c|c|c|c|}
\hline Parameter & $\mathrm{T}_{1}$ & $\mathrm{~T}_{2}$ & $\mathrm{~T}_{3}$ & $\mathrm{~T}_{4}$ & $\mathrm{~T}_{5}$ & $P$ \\
\hline $\mathrm{mABP}, \mathrm{mm} \mathrm{Hg}$ & $76.9 \pm 6.9$ & $78.5 \pm 9.0$ & $82.5 \pm 7.9$ & $79.5 \pm 7.3$ & $77.9 \pm 5.1$ & .44 \\
\hline $\mathrm{CVP}, \mathrm{cm} \mathrm{H}{ }_{2} \mathrm{O}$ & $13.1 \pm 1.2$ & $13.2 \pm 1.4$ & $14.2 \pm 1.3$ & $12.7 \pm 1.7$ & $12.5 \pm 1.0$ & .064 \\
\hline $\mathrm{mPAP}, \mathrm{mm} \mathrm{Hg}$ & $21.0 \pm 4.9$ & $21.5 \pm 5.2$ & $25.2 \pm 5.1$ & $23.1 \pm 5.1$ & $20.8 \pm 1.8$ & .15 \\
\hline$\dot{\mathrm{Q}}_{\mathrm{T}}, \mathrm{L} / \mathrm{min}$ & $4.9 \pm 1.4$ & $4.5 \pm 1.6$ & $3.8 \pm 1.1$ & $4.7 \pm 1.3$ & $5.4 \pm 1.1$ & .09 \\
\hline $\mathrm{P}_{\mathrm{aO}_{2}} / \mathrm{F}_{\mathrm{IO}_{2}}, \mathrm{~mm} \mathrm{Hg}$ & $335.4 \pm 48.6$ & $322.2 \pm 47.4$ & $300.4 \pm 59.1$ & $289.9 \pm 51.5$ & $321.5 \pm 37.6$ & .21 \\
\hline $\mathrm{P}_{\mathrm{aCO}_{2}}, \mathrm{~mm} \mathrm{Hg}$ & $38.9 \pm 2$ & $39.2 \pm 2.1$ & $39.4 \pm 2.2$ & $39.2 \pm 2.9$ & $39.3 \pm 2.1$ & .90 \\
\hline $\mathrm{Hb}, \mathrm{g} / \mathrm{dL}$ & $13.0 \pm 1.5$ & $12.8 \pm 1.4$ & $12.4 \pm 1.5$ & $11.4 \pm 1.5$ & $11.8 \pm 1.2$ & .058 \\
\hline $\begin{array}{l}\text { All values are mean } \pm \mathrm{S} \\
\mathrm{T}_{1}=10 \text { min after intuba } \\
\mathrm{T}_{2}=20 \text { min after intuba } \\
\mathrm{T}_{3}=\text { at the end of the re } \\
\mathrm{T}_{4}=\text { after protamine inf } \\
\mathrm{T}_{5}=10 \text { min after protan } \\
\mathrm{mABP}=\text { mean arterial b } \\
\mathrm{CVP}=\text { central venous } \mathrm{pr} \\
\mathrm{mPAP}=\text { mean pulmonar } \\
\dot{\mathrm{Q}}_{\mathrm{T}} \text {, cardiac output } \\
\mathrm{P}_{\mathrm{aO}}=\text { arterial oxygen } \mathrm{p} \\
\mathrm{F}_{\mathrm{IO}_{2}}=\text { fraction of inspire } \\
\mathrm{P}_{\mathrm{aCO}}=\text { arterial carbon } \mathrm{c} \\
\mathrm{Hb}=\text { hemoglobin }\end{array}$ & $\begin{array}{l}\left.\mathrm{IO}_{2} \text { for } 10 \mathrm{~min}\right) \\
\left.\mathrm{F}_{\mathrm{IO}_{2}} \text { for } 10 \mathrm{~min}\right) \\
\text { tion of the left anteri } \\
\left.\mathrm{F}_{\mathrm{IO}_{2}}\right) \\
\text { on }\left(1.0 \mathrm{~F}_{\mathrm{IO}_{2}} \text { for } 10 \mathrm{~m}\right. \\
\text { are } \\
\text { tressure } \\
\text { ssure }\end{array}$ & ling artery $\left(0.60 \mathrm{~F}_{\mathrm{IO}_{2}}\right.$ & & & & \\
\hline
\end{tabular}

Table 3. The Correlation Between $\mathrm{S}_{\overline{\mathrm{v}}_{2}}$ and $\mathrm{rScO}_{2}$

\begin{tabular}{|c|c|c|c|c|}
\hline Time Point & $\mathrm{S}_{\overline{\mathrm{v}}_{2}}$ & $\mathrm{rScO}_{2}$ & $r^{2}$ & $P$ \\
\hline $\mathrm{T}_{1}$ & $79.3 \pm 7$ & $64.4 \pm 3.8$ & 0.77 & $<.001$ \\
\hline $\mathrm{T}_{2}$ & $74.7 \pm 6.1$ & $61.3 \pm 3.6$ & 0.81 & $<.001$ \\
\hline $\mathrm{T}_{3}$ & $74.8 \pm 4.9$ & $61.8 \pm 3.1$ & 0.70 & $<.001$ \\
\hline $\mathrm{T}_{4}$ & $78.9 \pm 4.6$ & $62.7 \pm 3.1$ & 0.83 & $<.001$ \\
\hline $\mathrm{T}_{5}$ & $83.5 \pm 4.3$ & $64.6 \pm 3.0$ & 0.92 & $<.00$ \\
\hline \multicolumn{5}{|c|}{$\begin{array}{l}\text { All values are mean } \pm \text { SD. } \\
S_{\mathrm{V}_{2}}=\text { mixed venous oxygen saturation } \\
\mathrm{rScO}_{2}=\text { regional cerebral oxygenation } \\
\mathrm{T}_{1}=10 \text { min after intubation }\left(1.0 \mathrm{~F}_{\mathrm{IO}_{2}} \text { for } 10 \mathrm{~min}\right) \\
\mathrm{T}_{2}=20 \text { min after intubation }\left(0.60 \mathrm{~F}_{\mathrm{IO}_{2}} \text { for } 10 \mathrm{~min}\right) \\
\mathrm{T}_{3}=\text { at the end of the revascularization of the left anterior descending artery }\left(0.60 \mathrm{~F}_{\mathrm{IO}_{2}}\right) \\
\mathrm{T}_{4}=\text { after protamine infusion }\left(0.60 \mathrm{~F}_{\mathrm{IO}_{2}}\right) \\
\mathrm{T}_{5}=10 \text { min after protamine infusion }\left(1.0 \mathrm{~F}_{\mathrm{IO}_{2}} \text { for } 10 \mathrm{~min}\right)\end{array}$} \\
\hline
\end{tabular}

The linear regression analysis revealed that $\mathrm{S}_{\overline{\mathrm{v}} \mathrm{O}_{2}}$ was positively correlated with $\mathrm{rScO}_{2}$ and $\dot{\mathrm{Q}}_{\mathrm{T}}\left(\mathrm{r}^{2}=0.68, P=\right.$ .01). The regression equation was $\mathrm{S}_{\overline{\mathrm{v}} \mathrm{O}_{2}}=-16.082+$ $1.393 \times \mathrm{rScO}_{2}+1.304 \times \dot{\mathrm{Q}}_{\mathrm{T}}$.

\section{Discussion}

In the present study, a moderate-to-strong positive correlation was found between $\mathrm{rScO}_{2}$ and $\mathrm{S}_{\overline{\mathrm{v}}}$ during offpump coronary artery bypass grafting surgery. There also was a positive correlation on the variation trend between $\mathrm{rScO}_{2}$ and $\mathrm{S}_{\overline{\mathrm{v}}_{2}}$ when $\mathrm{F}_{\mathrm{IO}_{2}}$ was changed.

The $\mathrm{rScO}_{2}$, which can be noninvasively monitored by near-infrared spectroscopy, indicates the $\mathrm{rScO}_{2}$ and provides information on $\mathrm{rScO}_{2}$ delivery and consumption bal-

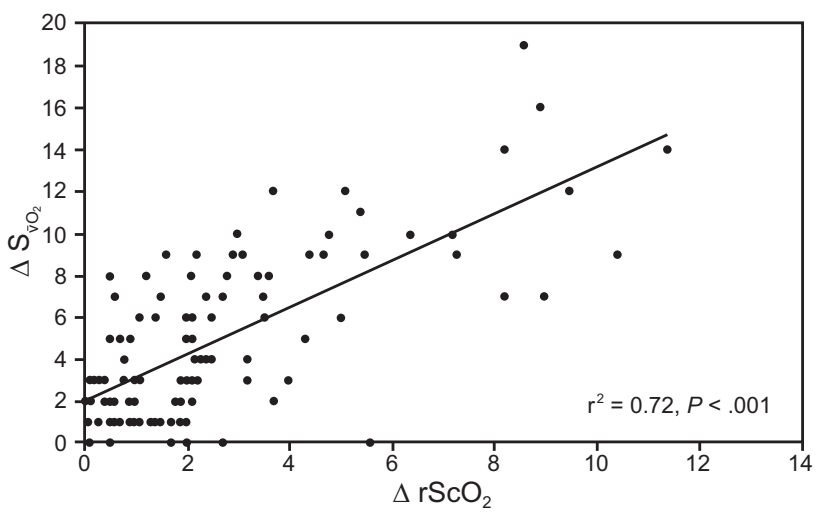

Fig. 2. Correlation between the change in the regional cerebral $\mathrm{O}_{2}$ saturation $\left(\Delta \mathrm{rScO}_{2}\right)$ and the change in the mixed venous $\mathrm{O}_{2}$ saturation $\left(\Delta \mathrm{S}_{\overline{\mathrm{vO}}_{2}}\right)$.

ance. $\mathrm{S}_{\overline{\mathrm{v}}_{2}}$ provides information on global oxygen delivery and consumption balance, and can be used as an indicator of the adequacy of whole-body oxygen, including venous saturation of the brain and of the upper and lower extremities. ${ }^{14}$ However, the trend of using a pulmonary artery catheter to monitor $\mathrm{S}_{\overline{\mathrm{v}}_{2}}$ has declined due to complications. ${ }^{15}$

Although $\mathrm{rScO}_{2}$ reflects oxygen saturation in the small region of the frontal lobes and depends on cerebral perfusion and metabolism, $\mathrm{S}_{\overline{\mathrm{v}}}$, represents the venous blood oxygen saturation of all organs and is dependent on wholebody oxygen delivery and consumption. Because blood in cerebral tissues mainly consists of the venous compartment, $\mathrm{rScO}_{2}$ is correlated closer to venous saturation than to arterial saturation. ${ }^{16}$ Hence, a positive correlation was 
found between $\mathrm{rScO}_{2}$ and $\mathrm{S}_{\overline{\mathrm{v}}}$ in the present study. Because the variation range was greater in $\mathrm{S}_{\overline{\mathrm{v}} \mathrm{O}_{2}}$ than in $\mathrm{rScO}_{2}$, there was a different $\mathrm{r}^{2}$ between $\mathrm{rScO}_{2}$ and $\mathrm{S}_{\overline{\mathrm{v}}}{ }_{2}$ at each time point.

Previous studies show that $\mathrm{rCcO}_{2}$ can reflect global oxygen delivery and consumption balance. Ginther et al ${ }^{17}$ found that the correlation coefficient between cerebral nearinfrared spectroscopy and superior vena cava oxygen saturation was 0.77 during cardiopulmonary bypass. During the varying hemodynamic conditions in subjects undergoing transapical transcatheter aortic valve implantation,

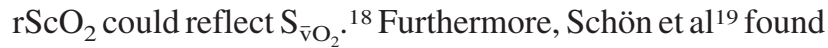
a positive correlation between $\mathrm{rScO}_{2}$ and $\mathrm{S}_{\overline{\mathrm{v}}}$ in awake and spontaneously breathing subjects after cardiac surgery. Weiss et al ${ }^{20}$ concluded that $\mathrm{rScO}_{2}$ is associated with central venous oxygen saturation. Kirshbom et $\mathrm{al}^{21}$ found that $\mathrm{rScO}_{2}$ can reflect systemic perfusion in awake children with a single ventricle. Other studies found a positive correlation among $\mathrm{rScO}_{2}, \mathrm{~S}_{\overline{\mathrm{v}} \mathrm{O}_{2}}$ and central venous oxygen saturation in pediatric cardiac surgery subjects. ${ }^{22,23}$ Furthermore, a positive correlation between $\mathrm{rScO}_{2}$ and $\mathrm{S}_{\overline{\mathrm{v}}} \mathrm{O}_{2}$ was also found during extracorporeal membrane oxygenation in a porcine model. ${ }^{24}$

Many factors can influence the $\mathrm{rScO}_{2}$ value. Dullenkopf et $\mathrm{al}^{12}$ found that there was a fair-to-moderate correlation in $\mathrm{rScO}_{2}$ with hemoglobin concentration and the cardiac index in adult subjects after cardiac surgery. Jugular bulb oxygen saturation, which can indicate $\mathrm{rScO}_{2},{ }^{25}$ decreased during coronary artery anastomosis in off-pump coronary artery bypass grafting surgery. ${ }^{26} \mathrm{Hu}$ et al ${ }^{27}$ found that $\mathrm{rScO}_{2}$ was positively correlated to cerebral perfusion pressure (approximately equal to mean arterial blood pressure-central venous pressure). In the present study, we found that $S_{\overline{\mathrm{v}} \mathrm{O}_{2}}$ was positively correlated with $\mathrm{rScO}_{2}$ and $\dot{\mathrm{Q}}_{\mathrm{T}}$, which indicated that the $\mathrm{S}_{\overline{\mathrm{v}}_{2}}$ and $\mathrm{rScO}_{2}$ could be interactional.

During anesthesia induction, $\mathrm{F}_{\mathrm{IO}_{2}}$ was set to 1.0 to increase the oxygen reserve and to prolong the artificial ventilation suspending time during trachea intubation. A previous study revealed that $1.0 \mathrm{~F}_{\mathrm{IO}_{2}}$ during anesthesia induction did not induce obvious atelectasis. ${ }^{28}$ To avoid atelectasis during the operation, $\mathrm{F}_{\mathrm{IO}_{2}}$ was reduced to 0.60 after endotracheal intubation. In addition, because hemoglobin, $\mathrm{S}_{\mathrm{aO}}$, hemodynamics, and oxygen consumption were relatively stable within 10 min during general anesthesia, we can only change $\mathrm{F}_{\mathrm{IO}_{2}}$ to change the oxygen delivery, which further influences the values of $\mathrm{rScO}_{2}$ and $\mathrm{S}_{\overline{\mathrm{v}} \mathrm{O}_{2}}$. A positive correlation on the variation trend between $\mathrm{rScO}_{2}$ and $\mathrm{S}_{\overline{\mathrm{v}} \mathrm{O}_{2}}$ was also found.

There were limitations in the present study. First, the study was limited to 2 different clinical conditions, and we did not perform this study over a range of varying $\mathrm{F}_{\mathrm{IO}_{2}}$ concentrations. Second, the hemodynamics was stable in all the subjects during the operation. However, there was no way to conclude whether the obtained correlations would be valid under unstable hemodynamic conditions. Third, these results were based on this condition, namely, that the oxygen supply and consumption function were normal; there would be different results when oxygenation and oxygen transfer capacity are impaired. Also, our study was limited by the relatively small number of subjects; as such, there may be some selection bias.

\section{Conclusions}

According to the present study, $\mathrm{rScO}_{2}$ would be adequate in reflecting $\mathrm{S}_{\overline{\mathrm{v}} \mathrm{O}_{2}}$ and the variation trend of $\mathrm{S}_{\overline{\mathrm{v}}} \mathrm{O}_{2}$ during off-pump coronary artery bypass grafting surgery. Furthermore, the change in $\mathrm{F}_{\mathrm{IO}_{2}}$ can simultaneously influence the $\mathrm{rScO}_{2}$ and $\mathrm{S}_{\overline{\mathrm{v}}}$, value, and the variation trend of $\mathrm{rScO}_{2}$ and $\mathrm{S}_{\overline{\mathrm{v}}}$ was consistent, which has not been reported before.

\section{REFERENCES}

1. Smartt $\mathrm{S}$. The pulmonary artery catheter: gold standard or redundant relic. J Perianesth Nurs 2005;20(6):373-379.

2. American Society of Anesthesiologists Task Force on Pulmonary Artery Catheterization. Practice guidelines for pulmonary artery catheterization: an updated report by the American Society of Anesthesiologists task force on pulmonary artery catheterization. Anesthesiology 2003;99(4):988-1014.

3. Hyttel-Sorensen S, Hessel TW, Greisen G. Peripheral tissue oximetry: comparing three commercial near-infrared spectroscopy oximeters on the forearm. J Clin Monit Comput 2014;28(2):149-155.

4. Scheeren TW, Schober P, Schwarte LA. Monitoring tissue oxygenation by near infrared spectroscopy (NIRS): background and current applications. J Clin Monit Comput 2012;26(4):279-287.

5. Sood BG, McLaughlin K, Cortez J. Near-infrared spectroscopy: applications in neonates. Semin Fetal Neonatal Med 2015;20(3):164172.

6. Vohra HA, Modi A, Ohri SK. Does use of intra-operative cerebral regional oxygen saturation monitoring during cardiac surgery lead to improved clinical outcomes? Interact Cardiovasc Thorac Surg 2009; 9(2):318-322.

7. Rosenthal G, Furmanov A, Itshayek E, Shoshan Y, Singh V. Assessment of a noninvasive cerebral oxygenation monitor in patients with severe traumatic brain injury. J Neurosurg 2014;120(4):901907.

8. Kussman BD, Wypij D, DiNardo JA, Newburger J, Jonas RA, Bartlett $\mathrm{J}$, et al. An evaluation of bilateral monitoring of cerebral oxygen saturation during pediatric cardiac surgery. Anesth Analg 2005; 101(5):1294-1300.

9. Zulueta JL, Vida VL, Perisinotto E, Pittarello D, Stellin G. Role of intraoperative regional oxygen saturation using near infrared spectroscopy in the prediction of low output syndrome after pediatric heart surgery. J Card Surg 2013;28(4):446-452.

10. Slater JP, Guarino T, Stack J, Vinod K, Bustami RT, Brown JM III, et al. Cerebral oxygen desaturation predicts cognitive decline and longer hospital stay after cardiac surgery. Ann Thorac Surg 2009; 87(1):36-44; discussion 44-45.

11. Murkin JM, Adams SJ, Novick RJ, Quantz M, Bainbridge D, Iglesias I, et al. Monitoring brain oxygen saturation during coronary bypass surgery: a randomized, prospective study. Anesth Analg 2007;104(1): 51-58. 


\section{Oxygen Saturation During Coronary Artery Bypass}

12. Dullenkopf A, Baulig W, Weiss M, Schmid ER. Cerebral nearinfrared spectroscopy in adult patients after cardiac surgery is not useful for monitoring absolute values but may reflect trends in venous oxygenation under clinical conditions. J Cardiothorac Vasc Anesth 2007;21(4):535-539.

13. Yeh T Jr, Gouldman J, Auden SM, Seremet V, Edmonds HL Jr, Cerrito PB, Austin EH III. Mixed venous oxygen saturation does not adequately predict cerebral perfusion during pediatric cardiopulmonary bypass. J Thorac Cardiovasc Surg 2001;122(1):192-193.

14. Tweddell JS, Ghanayem NS, Mussatto KA, Mitchell ME, Lamers LJ, Musa NL, et al. Mixed venous oxygen saturation monitoring after stage 1 palliation for hypoplastic left heart syndrome. Ann Thorac Surg 2007;84(4):1301-1310; discussion 1310-1311.

15. Wiener RS, Welch HG. Trends in the use of the pulmonary artery catheter in the United States, 1993-2004. JAMA 2007;298(4):423429.

16. Naulaers G, Meyns B, Miserez M, Leunens V, Van Huffel S, Casaer $\mathrm{P}$, et al. Use of tissue oxygenation index and fractional tissue oxygen extraction as non-invasive parameters for cerebral oxygenation. A validation study in piglets. Neonatology 2007;92(2):120-126.

17. Ginther R, Sebastian VA, Huang R, Leonard SR, Gorney R, Guleserian KJ, Forbess JM. Cerebral near-infrared spectroscopy during cardiopulmonary bypass predicts superior vena cava oxygen saturation. J Thorac Cardiovasc Surg 2011;142(2):359-365.

18. Paarmann H, Heringlake M, Heinze H, Hanke T, Sier H, Karsten J, Schön J. Non-invasive cerebral oxygenation reflects mixed venous oxygen saturation during the varying haemodynamic conditions in patients undergoing transapical transcatheter aortic valve implantation. Interact Cardiovasc Thorac Surg 2012;14(3):268-272.

19. Schön J, Heringlake M, Berger KU, Volker Groesdonk H, Sedemund-Adib B, Paarmann H. Relationship between mixed venous oxygen saturation and regional cerebral oxygenation in awake, spontaneously breathing cardiac surgery patients. Minerva Anestesiol 2011;77(10):952-958.

20. Weiss M, Dullenkopf A, Kolarova A, Schulz G, Frey B, Baenziger O. Near-infrared spectroscopic cerebral oxygenation reading in ne- onates and infants is associated with central venous oxygen saturation. Paediatr Anaesth 2005;15(2):102-109.

21. Kirshbom PM, Forbess JM, Kogon BE, Simsic JM, Kim DW, Raviele AA, et al. Cerebral near infrared spectroscopy is a reliable marker of systemic perfusion in awake single ventricle children. Pediatr Cardiol 2007;28(1):42-45.

22. Marimón GA, Dockery WK, Sheridan MJ, Agarwal S. Near-infrared spectroscopy cerebral and somatic (renal) oxygen saturation correlation to continuous venous oxygen saturation via intravenous oximetry catheter. J Crit Care 2012;27(3):314.e13-314.e18.

23. Nagdyman N, Fleck T, Barth S, Abdul-Khaliq H, Stiller B, Ewert P, et al. Relation of cerebral tissue oxygenation index to central venous oxygen saturation in children. Intensive Care Med 2004;30(3):468471.

24. Tyree K, Tyree M, DiGeronimo R. Correlation of brain tissue oxygen tension with cerebral near-infrared spectroscopy and mixed venous oxygen saturation during extracorporeal membrane oxygenation. Perfusion 2009;24(5):325-331.

25. Ikeda K, MacLeod DB, Grocott HP, Moretti EW, Ames W, Vacchiano $\mathrm{C}$. The accuracy of a near-infrared spectroscopy cerebral oximetry device and its potential value for estimating jugular venous oxygen saturation. Anesth Analg 2014;119(6):1381-1392.

26. Kim JY, Kwak YL, Oh YJ, Kim SH, Yoo KJ, Hong YW. Changes in jugular bulb oxygen saturation during off-pump coronary artery bypass graft surgery. Acta Anaesthesiol Scand 2005;49(7): 956-961.

27. Hu Z, Xu L, Zhu Z, Seal R, McQuillan PM. Effects of hypothermic cardiopulmonary bypass on internal jugular bulb venous oxygen saturation, cerebral oxygen saturation, and bispectral index in pediatric patients undergoing cardiac surgery: a prospective study. Medicine (Baltimore) 2016;95(2):e2483

28. Kanaya A, Satoh D, Kurosawa S. Higher fraction of inspired oxygen in anesthesia induction does not affect functional residual capacity reduction after intubation: a comparative study of higher and lower oxygen concentration. J Anesth 2013;27(3):385-389. 